\title{
The role of the audit committee in strengthening business ethics and protecting stakeholders' interests
}

\author{
Ben Marx \\ Gideon Els
}

\begin{abstract}
It is imperative for companies to do business ethically and to respect the rights of all the company's stakeholders, while still being accountable to the shareholders. This article examines evidence from a literature and empirical study conducted on the role of audit committees in strengthening business ethics and protecting stakeholders' interests. The study found that the majority of audit committee chairs believe their audit committees to be effective in discharging their responsibilities regarding business ethics. Of concern, however, are the findings that a large number of audit committees are not reviewing compliance with their companies' code of ethics, although most of them are reviewing or providing a channel for whistle-blowing. The inspection of the annual reports further indicated a lack of disclosure by the audit committees on their responsibilities regarding business ethics.
\end{abstract}

Key words: audit committees, business ethics, Second King Report on Corporate Governance (King II), Third King Report on Corporate Governance (King III), stakeholder interest, stakeholder theory

\section{Introduction}

The evolving concepts of business ethics and stakeholder rights are not mere financial jargon or flavour-of-themonth buzzwords, but key aspects of the modern business environment. Doing business ethically and in a responsible manner will not only contribute to the shortterm profitability of a business, but may also ensure its long-term survival.

The Second King Report on Corporate Governance (King II) acknowledged the shift in emphasis from the mainly financial focus of the past to a wider and more inclusive approach of doing business in the future. In this regard King II states (Institute of Directors (IoD), 2002, p. 20, par. 41):'Successful governance in the world in the 21st century requires companies to adopt an inclusive and not exclusive approach ... there must be greater emphasis on the sustainable or non financial aspects of its performance. Boards must apply the test of fairness, accountability, responsibility and transparency to all acts or omissions and be accountable to the company but also responsive and responsible towards the company's identified stakeholders.'

Ben Marx is professor in Auditing in the Department of Accountancy at the University of Johannesburg. He has researched and written extensively on the issue of audit committees.

Gideon Els is head of the department of Finance and Investment Management at the University of Johannesburg. His research focus is on business ethics and education.
The Third King Report on Corporate Governance (King III), released for public comment on the 25 February 2009 (IoD, 2009), builds further on these concepts and places great emphasis on corporate citizenship and ethics. In this regard, the report states that 'The board should ensure that the company acts as and is seen to be a responsible corporate citizen' (IoD, 2009, par. 2.1).

The myriad examples of corporate collapses, business failures and fraudulent financial reporting found in business today all had in common the elements of greed, fraud and a lack of ethical conduct. According to Hutton-Wilson (2001), these businesses also lacked the basic values of honesty, integrity, transparency and accountability - those being the four key pillars of corporate governance and business ethics (the original four pillars of corporate governance as per King I).

Arthur Levitt, former chairman of the SEC, described the collapses of ethical behaviour in the corporate world as a 'moral cancer' and stated that he is of the opinion that a 'new ethical compass' is required (Robins, 2006).

\section{Research objective}

The focus of corporate governance over the years has shifted in emphasis from the mainly financial focus in the past to a wider and more inclusive approach of doing business, with a high level of emphasis being placed on corporate citizenship and ethics. Accordingly it is imperative for companies to do business ethically and to respect the rights of all the company's stakeholders, while still being accountable to the shareholders. In this regard an effectively functioning audit committee can play an important role in assisting the board to strengthen business ethics and protect wider stakeholder interests. The objective of the article is to provide evidence from both a literature and an empirical perspective on the role of the audit committee in strengthening business ethics and protecting stakeholders' interests.

\section{Business ethics}

\section{Defining business ethics}

Ethics is derived from the Greek words ethos or ethikos, which means character, and as such the subject of ethics is as old as humanity itself (Els, 2007). Wheelwright (in Robertson, 1993:118) defined ethics as 'that branch of philosophy which is the systematic study of reflective choice, of the standards of right and wrong by which 
it is to be guided, and of the good toward which it may ultimately be directed'.

In this definition, one can detect three key elements:

- ethics involve questions requiring reflective choice (decision problems);

- ethics involve guides of right and wrong (moral principles); and

- ethics are concerned with the consequences of decisions.

Griseri $(1997: 11)$ is of the opinion that business and ethics cannot be separated. Unethical business practice has its own costs. Although these costs may not be immediately obvious they may appear at a later stage at a much higher level. Kidder (2001) goes even further and advocates that there is no such thing as 'non-profit ethics'. Indeed, he declares that business ethics does not exist, '... only ethics'.

Various definitions and meanings have been ascribed over the years to the concepts of ethics and ethical behaviour. Rossouw (2002:4) describes ethical behaviour as 'behaviour that considers not only what is good for oneself but also what is good for others', while Rossouw and Van Vuuren (2004:3) describe ethics as concerning itself '... with what is good or right in human interaction'. They state that ethics resolve around three central concepts, namely 'self, good and other' and declare that it is important that each of these three central concepts be included in a definition of ethics. Thomas (2008:30), in a discussion on the need for business ethics, states that '... ethics is concerned with how a moral person should behave ...' and is of the opinion that this applies to both individuals and business.

One of the earlier definitions of business ethics is that of Velasquez (in Breckenridge, 2004:5), who in 1988 defined business ethics as follows: 'Business ethics is applied ethics. It is the application of our understanding of what is good and right to that assortment of institutions, technologies, transactions, activities and pursuits which we call "Business".'

Since then many definitions have been ascribed to the term 'business ethics'. One of the more recent explanations of business ethics is that of Rossouw et al. (2007:6), who describe business ethics as follows: 'While ethics in general deals with what is good or right in human interaction (and interaction between humans and animals and the environment) business ethics focuses on what is good and right in economic activity specifically. It therefore focuses on morally evaluating economic practices and activities.'

The concept of business ethics has accordingly evolved from the age-old principles of ethics to an important concept and essential part of the modern business environment.

\section{The importance of business ethics}

Doing business in an ethical manner is essential for the profitability and long-term survival of the modern company. According to Rossouw (2003), the failure by companies to behave ethically can have serious detrimental effects for them and their shareholders: 'many a company has been ruined as a result of unethical behaviour. The opposite is equally true companies stand to benefit substantially from ethical behaviour. In this sense, the ethical performance of companies is a genuine risk factor' (Rossouw, 2003:3). Landman (2006:49) supports the arguments of Rossouw and is of the opinion that compliance with sound business ethics principles will reduce the risk of unethical conduct taking place which could damage the company's reputation and future existence. Similarly, Rossouw and Van Vuuren (2004:1) are of the opinion that 'business should make ethical sense, but ethics can also make business sense.' The draft of King III (IoD, 2009, par. $2.1 \& 2.4$.) further builds on the importance of ethics and corporate integrity by stating in the code that '... the board should ensure the company acts as and is seen to be a responsible corporate citizen ...' and '... the board should actively manage the company's ethics performance.'

Had business ethics been the centre of management's conduct at WorldCom, Enron, LeisureNet, Fidentia and the other well-known corporations that have collapsed in recent times, those fraudulent financial reporting and other irregularities might never have occurred or prevailed (Knights \& O'Leary, 2005). Accordingly, the various stakeholders might have been spared the financial hardship and other consequences they suffered.

\section{The role of audit committees}

The audit committee, consisting of independent nonexecutive directors who are financially literate and who should have the necessary financial expertise amongst themselves, are ideally suited to oversee and strengthen the company's ethical compliance and related business practices.

\section{Suitability of audit committees}

The main reasons why the audit committee has the capacity for this oversight role are as follows:

\section{Focused committee structure}

The audit committee, being a small sub-committee of the board with a focused brief, is much better placed to oversee the company's compliance with business ethics, than either the full board or a single individual. The status and seniority of the audit committee, and the fact that it is generally regarded as the most important sub-committee of the board, will further strengthen the importance of business ethics if the oversight responsibility falls under its remit. 


\section{Integration with other responsibilities}

The various corporate governance codes normally task the audit committee with the responsibility of overseeing the company's compliance with laws and regulations and the company's code of conduct. As such the audit committee already has oversight responsibilities for part of the company's ethical and legal aspects, and it makes sense to extend this responsibility to include the full coverage of business ethics compliance. This view is supported as follows by PricewaterhouseCoopers (2005:23): 'audit committees increasingly have responsibility for monitoring ethics and compliance with laws and regulations and for establishing and overseeing "whistleblower" hotlines.'

The audit committee's interaction with the internal and external auditors will also provide it with useful information to assess the company's ethical practices and compliance. Thus the other responsibilities of the audit committee will complement the responsibility for business ethics oversight.

\section{Audit committee members' education and training}

An effective audit committee should consist of members who are all financially literate with sufficient financial expertise amongst them. This would normally require schooling in accounting and/or auditing. As part of the curriculum of Accounting Studies, students take the subject of Auditing, which covers the area of professional ethics. Furthermore, the International Federation of Accountants (IFAC) has placed increased emphasis on the teaching of business ethics at university level, with the result that Business Ethics now forms part of the Accounting curriculum of most universities (IFAC, 2002; Els, 2007; Williams, 2007b).

Members of professional accounting bodies are also required to complete training contracts. During these training contracts they are provided with guidance on applied ethics and how to deal with ethical problems (Knechel et al., 2007). After qualifying they should also meet certain continuing professional development (CPD) criteria, which include criteria for business ethics (Els, 2007).

As part of their financial reporting and control oversight responsibilities, audit committees are reviewing various forms of financial reporting, and are working through various reports and information on internal control and risk management systems. Given their accounting and auditing backgrounds and training they would be well suited to identify possible fraudulent financial reporting practices, collusion and possible areas of fraud.

\section{Audit committee members' professional obligations to act ethically}

Many audit committee members are, as stated above, members of a professional accounting body. Most of these bodies are members of IFAC (for example SAICA,
CIMA, ACCA etc.). IFAC produced a statement on ethics in 2001 and followed this up with a comprehensive Code of Ethics for Professional Accountants (IFAC, 2005) and accordingly members of professional accounting bodies are required to comply with the Code of Professional Ethics.

In a research study done by Maree and Radloff (2007) regarding factors affecting the ethical judgement of South African chartered accountants, they found strong supporting evidence that ethics can be taught at university and that chartered accountants are in support of the South African Institute of Chartered Accountants' (SAICA) Code of Professional Conduct. Accordingly, audit committee members who are registered with a professional accounting body are compelled to act ethically. This makes them very suitable to oversee the company's ethical compliance and business conduct as audit committee members.

\section{The role of the audit committee in strengthening business ethics}

The audit committee can fulfil a very important oversight responsibility regarding the company's ethical compliance and the fostering of a culture of doing business ethically. The ways this can be achieved are described, inter alia, below.

\section{The 'tone' at the top}

The company should have a culture of the highest business ethics. It is well accepted that the 'tone' for a company should be set at the 'top'; that is by the board and executive management. If the board and executive management act ethically and honestly, it should set an example for employees to follow (Schäckermann, 2007). The important role of directors in this regard is emphasised as follows by Schwarts et al. (2005:79) in their research report on the ethical conduct of directors: 'The ethical role of directors is critical. Directors have overall responsibility for the ethics and compliance programmes of the corporation. The tone at the top that they set by example and action is central to the overall environment of their firms. The role is reinforced by their legal responsibilities to provide oversight of the financial performance of the firm. Underlying this analysis is the critical assumption that ethical behaviour, especially on the part of corporate leaders, leads to the best long term interests of the corporation.'

Thomas (2005) emphasises that leadership has the '... responsibility for "walking the talk" and developing the organisational context for sound governance is paramount' (Thomas, 2005:80). The responsibility for acting ethically, setting an ethical example and adhering at all times to sound business ethics principles is the 
responsibility of every director, management executive and employee. The audit committee is, however, very well placed to act as the conscience of the board and to take oversight responsibility for business ethics.

\section{Ethics policies and codes}

The King II Report recommends that every company should have a code of ethics and that the custodianship of this should reside with the audit committee (IoD, 2002; Deloitte, 2006). This is supported as follows by Bromilow and Berlin (2005:35) based on research regarding audit committee effectiveness and best practices: 'Increasingly, audit committees must monitor ethics and codes of conduct, as well as compliance with laws and regulations. Leading practices of code of conduct oversight include ensuring that a robust, written code has been developed and assuring the board itself receives a copy of the code and related training.'

\section{Monitoring ethical compliance}

In performing its monitoring oversight role regarding the company's business ethics practices and ethical compliance, the internal and external auditors can be of great assistance to the audit committee. Besides the normal interaction with the auditors regarding financial reporting, internal control and risk management systems, the audit committee should have a separate agenda item, questioning both the internal and external auditors on the company's business ethics compliance, and any audit findings or concerns they might have in this regard. Such enquiry should also be directed at management, represented normally by the $\mathrm{CEO}$ and $\mathrm{CFO}$, and, where an ethics and compliance officer exists, to him/her as well.

The audit committee should also consider the viability and necessity of having an ethics audit done from time to time. These audits can be performed by either internal audit or suitably qualified external consultants (Punt, 2006). The important role of internal audit regarding the evolving responsibility for conducting ethics audits, and the value thereof, is stated as follows by Jackson (2006:40): 'Internal auditors who conduct ethics audits can help prevent inappropriate activities from being swept under the rug and ensure the organisation's reputation remains spotless.'

Monitoring of ethics should happen at normal audit committee meetings. However, serious ethical transgressions or concerns should be reported immediately to the audit committee chair, who would then decide on the appropriate course of action.

\section{Financial reporting}

The main objective of the audit committee is to improve the quality of the financial reporting process and the accuracy, integrity and reliability of the financial statements. In performing this oversight responsibility the audit committee will place reliance on the work of management, internal audit and especially that of the external auditors.

The audit committee should, however, not only concern itself with financial reporting, but should also monitor and oversee the accuracy and reliability of other forms of stakeholder reporting, such as sustainability reports.

\section{Fraud}

The audit committee has a very important role to play regarding fraud and overseeing fraud risk management. In this regard audit committees can play an important role in preventing, detecting and investigating fraud (Ernst \& Young, 2007). As far as fraud prevention is concerned, Ernst \& Young (2006) is of the opinion that 'the most powerful thing an audit committee can bring to fraud prevention is consistency of expectations for management and for external auditors.'

As far as fraud is concerned, the audit committee should have a policy of zero tolerance, and all instances of fraud should be taken seriously, investigated and acted upon. Everybody in the company, from the CEO to the 'gatekeeper', should be aware of this.

\section{Corporate governance and stakeholder protection}

\section{Introduction}

The development of corporate governance gave prominence to the need for businesses to behave in a responsible and ethical manner. The modern company has the responsibility of being a responsible corporate citizen, while remaining accountable to its shareholders. Accordingly, it must work towards ensuring the sustainability of the company by achieving a balanced and integrated economic, social and environmental performance. Corporate citizenship and stakeholder engagement is important for the reasons stated above, but can also bring significant benefits to the company (Leeman, 2002). According to Gatamah (2006), companies that are good corporate citizens also have a competitive edge when competing in global markets.

As discussed before, there was a move from profits for shareholders only (single bottom line) to the recognition that business has a responsibility to those who give it its licence to operate, namely its stakeholders at large (triple bottom line). This gave rise to the concepts of corporate citizenship, sustainability and triple bottom line reporting. These concepts are discussed below:

\section{Definition of stakeholder-related concepts}

The stakeholder theory is a theory of both organisational management and business ethics that addresses morals and values in managing a business entity. It was originally 
detailed by R. Edward Freeman in the book Strategic Management: A Stakeholder Approach (Freeman, 1984), and identifies and models the groups which are stakeholders of a business entity, and both describes and recommends methods by which management can give due regard to the interests of those groups.

The same belief was held by Edward Freeman (Rossouw \& Van Vuuren, 2004). Freeman (in Breckenridge, 2004:27) defined stakeholders as 'any group or individual who can affect or is affected by the achievement of the organisation's objectives.'

\section{Suitability of the audit committee to oversee stakeholder reporting}

Stakeholders are interested in both financial and nonfinancial information regarding the company and its operations. Financial information will be provided through the annual report, while non-financial reporting should focus on environmental, social, transformational and ethical aspects and safety and health information, and will normally be provided as part of the annual report, or in a separate sustainability report. It is also considered good business practice that such information be made available through electronic means and on the company's website.

Stakeholders want information that is reliable, accurate and credible to base their decisions on. As is the case with financial reporting, the audit committee can play a key oversight role in this regard - a statement that Williams (2007a) also agrees with.

By assuming oversight responsibility for stakeholder reporting the audit committee can ensure that the nonfinancial reporting information, which the stakeholders use to base their decisions on, is accurate, reliable and credible. This will in turn contribute to the protection and advancement of the individual stakeholder interests.

It should be noted that the draft King III report now requires of audit committees in the code to take oversight responsibility on the board's behalf for integrated sustainability reporting (IoD, 2009, par. 3.2.4).

\section{Methodology}

\section{Research design}

The role of the audit committee in strengthening business ethics and protecting stakeholders' interests was empirically tested (as part of a bigger study) through content analysis by way of an inspection of the annual reports and through questionnaires that were sent to CFOs and audit committee chairs for completion. The empirical study was of a descriptive nature focusing on the quality of information obtained rather than the quantitative nature of data. This approach is supported by Henning et al. (2004), who stress the importance of capturing the views of the subjects in the population. Content analysis is a methodology found predominantly in the social sciences for studying the content of communication (i.e. communication by way of annual financial statements). Holsti (1969) offers a broad definition of content analysis as 'any technique for making inferences by objectively and systematically identifying specified characteristics of messages.'

\section{Sample selection}

The study focused on audit committees at large listed companies in South Africa and accordingly the population for the empirical study was selected as the largest 40 companies ranked by market capitalisation in the JSE's All-Share Index (FTSE/JSE Top 40 Index) (JSE, 2007). On 27 February 2008 the companies of the FTSE/JSE Top 40 Index represented $87.64 \%$ of the total market value of the JSE's All-Share Index (Burke ${ }^{1}$, personal communication).

All 40 companies in the stated sample were included in the empirical study, and their names are listed in Table A in an Annexure to this article. On 27 February 2008 both Investec Ltd and Investec PLC, being a dual-listed company, were included in the Index, bringing the Index total to 41 companies. Because both companies have the same persons acting as CFO and audit committee chair, only Investec Ltd was included in the population, bringing the total number of companies in the population back to 40 .

\section{Research methods}

As stated above, the empirical study consisted of (i) a content analysis of the annual reports of all companies listed on the FTSE/JSE Top 40 Index; and (ii) the completion of questionnaires by the CFOs and audit committee chairs of these companies.

\section{Content analysis of annual reports}

The most recently available annual reports of the companies listed on the FTSE/JSE Top 40 Index were inspected between 25 and 28 March 2008. This was done at the offices of the JSE Limited (JSE) in Johannesburg, or on the companies' websites in cases where the latest annual reports had not yet been received by the JSE (companies have six months to submit hard copies of their financial statements to the JSE). The inspection of the annual reports was informed by the literature study, and in turn shaped the way the questionnaire was designed.

The control document used in the inspection of the annual reports to record the data is available on request. For the purposes of this article, the following issues are pertinent:

- the existence of subcommittees of the board;

- the composition of the audit committee; 
* the characteristics of the audit committee's members; and

* audit committee's responsibilities but specifically responsibilities around issues of business ethics.

\section{Questionnaires to CFOs and chairs of audit committees}

The second part of the empirical study consisted of questionnaires (available upon request) that were sent for completion to the CFOs and the chairs of audit committees of the 40 companies. Both questionnaires were e-mailed to the CFOs, who were requested to complete the questionnaire for the CFO and to pass the second attached questionnaire (questionnaire for the audit committee chair) on to the chair of the audit committee for completion. The questionnaires were sent electronically to the CFOs by e-mail under a covering message from the JSE's executive director of listings in which he expressed support for the empirical study and requested CFOs and the chairs of their audit committees to complete the questionnaires.

\section{Research control}

The respondents to whom the questionnaires were sent are all considered to be highly respected and conscientious members of the business community, and as such it was expected that they would exercise care in completing the questionnaires. This was further supported by Voogt (2008), who found that, as at 30 November 2007, 39 of the 40 CFOs of the FTSE/JSE Top 40 companies were chartered accountants and that it could be expected that they would exercise care in the completion of the questionnaires. Similar considerations apply for the audit committee chairs, as most of them are members of an accounting body, conscientious and well respected in the business community.

The data was processed and analysed by the researcher with the help of a chartered accountant and former academic. The processed data and results were reviewed independently for accuracy by another chartered accountant and fellow academic from the University of Johannesburg.

\section{Response rate}

In literature on audit committees, the general response rates for both empirical studies as well as those of professional surveys are relatively low. In this regard Brewer (2001) reported response rates of between $21.0 \%$ to a maximum of $61.0 \%$ for empirical research on audit committees conducted in the USA between 1970 and 1998. More recently Hadden (2002) reported a response rate of $5.47 \%$ and Weiss (2005) a response rate of $10.0 \%$ for empirical studies involving audit committees in the USA. From the limited research that had been done to date on audit committees in South Africa, the most recent empirical study of audit committees at companies in South Africa reported a response rate of 37.6\% in 2000 (Brewer, 2001).

The response rate for professional surveys is not much better: PricewaterhouseCoopers (2005) reported a response rate of $17.0 \%$ for their surveys of audit committee chairs in the USA in 2005. Ernst \& Young (2005) reported a response rate of $25.0 \%$ for their survey of audit committees at listed companies in South Africa in 2005.

For the annual report analysis a 100\% response was achieved, as all 40 companies' annual reports were inspected. For both questionnaires a response rate of $82.5 \%(n=34)$ was achieved, which is considered very high, and which substantiates the reliability of the empirical results. The response rates are detailed in Table 1 below.

TABLE 1: ReSPONSE RATE

\begin{tabular}{lcccc}
\hline & $\begin{array}{c}\text { Questionnaire A } \\
\text { (CFOs) }\end{array}$ & \multicolumn{2}{c}{$\begin{array}{c}\text { Questionnaire B } \\
\text { (Audit committee } \\
\text { chairs) }\end{array}$} \\
\cline { 2 - 5 } & Number & $\%$ & Number & $\%$ \\
\hline No response & 4 & 10.0 & 4 & 10.0 \\
\hline $\begin{array}{l}\text { Correspondence received } \\
\text { - policy is to not complete } \\
\text { questionnaires or surveys }\end{array}$ & 2 & 5.0 & 2 & 5.0 \\
\hline $\begin{array}{l}\text { Completed and usable } \\
\text { questionnaires }\end{array}$ & 34 & 85.0 & 34 & 85.0 \\
\hline TOTAL & 40 & 100.0 & 40 & 100.0 \\
\hline
\end{tabular}

\section{Analysis and interpretation of results from the} empirical study

\section{Board subcommittees}

As part of the content analysis of the annual reports, one focus area dealt with the existence of an audit committee and other board subcommittees. Table 2 summarises the findings below.

TABLE 2: OTHER SUBCOMMITTEES OF THE BOARD

\begin{tabular}{lcc}
\hline & Number & $\%$ \\
\hline Total companies in the population & 40 & 100 \\
\hline Remuneration committee & 34 & 85.0 \\
Risk management committee & 17 & 42.5 \\
Corporate governance committee & 1 & 2.5 \\
Ethics committee & 0 & 0.0 \\
Other committees & 34 & 85.0 \\
\hline
\end{tabular}

The above findings confirm the important role that subcommittees fulfil in the governance structures of boards. King II (IoD, 2002) also recognised the important role of committees in assisting the board and its directors in discharging their duties and 
responsibilities and recommends that all companies should, as a minimum, have an audit committee and a remuneration committee and such other committees as the industry and company-specific circumstances dictate. This important role is further encouraged in King III (IoD, 2009, par. 1.24).

The above findings further support the recommendations of King II and King III, as all 40 companies have audit committees and all 40 companies also have a remuneration committee by name (34), or another board committee fulfilling the role of a remuneration committee (6). These other six committees go under different names, such as human resource, directors' affairs or compensation committee, but all describe in their committee disclosure the fact that they are responsible for determining directors' remuneration.

The other committees of the board not specified above represent a wide spectrum of interests, such as committees for Strategic Innovation Management; Directors' Governance and Affairs; Credit; Board Finance/Oversight; Acquisition and Implementation; Nomination; Safety, Health and Environment; Sustainable Development; Empowerment/Transformation/BEE/ Employment Equity; Capital Projects and Tender Evaluations.

The above findings also confirm the important and evolving role of risk management, as 17 separate risk management committees were reported to exist. Given the importance of corporate governance and business ethics it is alarming to note that only one company has a stand-alone corporate governance committee and that none of the companies have an ethics committee. This could be an indication that some of these responsibilities are performed, albeit by the audit committee.

\section{Qualifications of audit committee members}

As part of the content analysis of annual reports, the composition of the audit committee and the characteristics of its members were investigated.

TABle 3: QUALIFICATION OF AUdiT COMMITTEE MEMBERS

\begin{tabular}{lccc}
\hline Type of qualification (highest) & Total & Average & $\begin{array}{c}\text { \% per average } \\
\text { audit committee } \\
\text { size of 4.15 } \\
\text { members }\end{array}$ \\
\hline B degree in accounting to D degree & 61 & 1.74 & 41.9 \\
\hline $\begin{array}{l}\text { Other business-related degrees } \\
\text { (including MBA/MBL) }\end{array}$ & 35 & 1.00 & 24.1 \\
\hline $\begin{array}{l}\text { Law qualification (degree or } \\
\text { diploma) }\end{array}$ & 10 & 0.29 & 7.0 \\
\hline $\begin{array}{l}\text { IT qualification (degree or diploma) } \\
\text { CIMA }\end{array}$ & 1 & 0.03 & 0.7 \\
\hline $\begin{array}{l}\text { CA(SA) or equivalent (ACCA, CPA, } \\
\text { FCA, etc) }\end{array}$ & 72 & 0.14 & 3.4 \\
\hline CIA (Internal auditor) & 0 & 0.00 & 50.4 \\
\hline $\begin{array}{l}\text { Other (e.g. HR Management, } \\
\text { Engineering etc.) }\end{array}$ & 26 & 0.74 & 17.8 \\
\hline
\end{tabular}

Table 3 indicates that the average audit committee consists of $41.9 \%$ of members with at least an undergraduate degree or higher in accounting and $50.4 \%$ of members with a professional accounting qualification (e.g. CA, ACCA, FCA etc.). A further analysis indicates that at least $66.0 \%$ of the members have a business-related degree ( $41.9 \%$ plus $24.1 \%$ ), which may be taken to imply that they should be able to read and understand financial statements, and therefore may be classified as financially literate. The highest number of members on an audit committee with a professional accounting qualification is seven (out of a total of eight members), while all the audit committees have at least one member with a professional accounting qualification.

Of interest is the fact that the other business-related degrees are mainly MBA qualifications. Of concern is the fact that certain members serving on the audit committee appear to lack accounting qualifications or experience. This might be so in fact, or such an impression might be created because of the poor quality of disclosure regarding their qualifications and/or experience.

\section{Financial literacy and financial expertise of audit committee members}

A further objective of the content analysis was to determine whether companies disclose information on whether their audit committee members are financially literate and whether there is sufficient financial expertise in their audit committees.

TABle 4: FinANCIAL Literacy OF AUDIT COMMITTEE MEMBERS

\begin{tabular}{|c|c|c|c|c|c|}
\hline & \multicolumn{3}{|c|}{ Number } & \multicolumn{2}{|c|}{$\%$} \\
\hline & Total & Yes & No & Yes & No \\
\hline $\begin{array}{l}\text { Statements on whether members are } \\
\text { financially literate }\end{array}$ & 40 & 14 & 26 & 35.0 & 65.0 \\
\hline Is literacy described? & 14 & 6 & 8 & 42.9 & 57.1 \\
\hline $\begin{array}{l}\text { How many members are financially } \\
\text { literate? }\end{array}$ & & & & & \\
\hline One member & & & & & \\
\hline Two member & 0 & & & 0.0 & \\
\hline Three or more members & 0 & & & 0.0 & \\
\hline All the members & $\begin{array}{c}1 \\
13\end{array}$ & & & $\begin{array}{c}7.1 \\
92.9\end{array}$ & \\
\hline TOTAL & 14 & & & 100.0 & \\
\hline
\end{tabular}

From Table 4 it is disappointing to note that only 14 companies (35.0\%) stated that their audit committee members are financially literate, and of those who did, only six (42.9\%) described this as 'financial literacy'.

An audit committee can only be effective if it is constituted of members who are independent and who have the necessary financial experience and expertise to understand and effectively deal with financial reporting, control and risk management and related aspects. The fact that only 14 (35.0\%) of the companies are prepared to 
state that their audit committee members are financially literate is of concern and raises questions regarding the effectiveness (or perceived effectiveness) of their audit committees.

TABLE 5: FinANCIAL EXPERTISE OF AUDIT COMMITTEE MEMBERS

\begin{tabular}{lccccc}
\hline & \multicolumn{3}{c}{ Number } & \multicolumn{2}{c}{$\%$} \\
\cline { 2 - 6 } & Total & Yes & No & Yes & No \\
\hline $\begin{array}{l}\text { Is there a financial expert on the } \\
\text { audit committee? }\end{array}$ & 40 & 11 & 29 & 27.5 & 72.5 \\
\hline
\end{tabular}

Source: Annual report disclosure (authors' analysis)

The same argument for financial expertise as for the financial literacy of audit committee members applies. The fact that only 11 (27.5\%) of the companies disclosed that there is sufficient financial expertise in their audit committee is of concern and could seriously affect the effectiveness or perceived effectiveness of their audit committees.

As stated in Table 3, the average audit committee consists of at least two members who have a professional accounting qualification and would thus meet the requirements for financial experience and/or expertise on the audit committee. It accordingly appears that there might not be a lack of members with financial expertise on audit committees, but that it is rather a matter of poor audit committee disclosure by companies regarding their audit committee members' qualifications and experience.

\section{Disclosure of audit committee responsibilities performed}

A further objective of the content analysis was to analyse the audit committees' various responsibilities, but specifically responsibilities around the issue of business ethics.

TABLE 6: AUdiT COMMITTEE RESPONSIBILITIES DISCLOSED IN THE ANNUAL REPORT

\begin{tabular}{lccccc}
\hline \multirow{2}{*}{ Business ethics } & \multicolumn{3}{c}{ Number } & \multicolumn{2}{c}{$\%$} \\
\cline { 2 - 6 } & Total & Yes & No & Yes & No \\
\hline $\begin{array}{l}\text { Review compliance with the } \\
\text { company's code of ethics }\end{array}$ & 40 & 10 & 30 & 25.0 & 75.0 \\
\hline $\begin{array}{l}\text { Review/Provide a channel for safe } \\
\text { reporting (whistle-blowing) }\end{array}$ & 40 & 8 & 32 & 20.0 & 80.0 \\
\hline $\begin{array}{l}\text { Other business ethics-related responsibilities performed by the audit } \\
\text { committee and disclosed as such includes the review of unethical conduct } \\
\text { and fraud by employees. }\end{array}$ & & & & \\
\hline
\end{tabular}

Source: Annual report disclosure (authors' analysis)

Based on the information found in Table 6, it is disconcerting to note that, by way of annual report disclosure, only $25.0 \%$ of the companies review compliance with the company's code of ethics and only
$20.0 \%$ review or provide a channel for safe reporting (whistle-blowing).

In terms of questionnaires sent to audit chairs, the following question was posed to audit committee chairs: 'Are you of the opinion that your audit committee is effective in discharging its responsibilities regarding business ethics?' Comparing this information now with the information gathered from Table 6 provides for interesting reading.

Only 28 (or $82.4 \%$ ) of the respondents (audit committee chairs) affirmed that their audit committee is effective to a large extent in discharging its responsibilities regarding business ethics, with six (or 18.6\%) stating that it does so to a lesser extent. As one of the respondents noted: 'The company has a separate risk committee chaired by myself with basically the same members as the audit and actuarial committee. Business ethics issues and fraud/ defalcation reports are presently not tabled but we will do so in future. There are numerous regulations and laws governing this industry. There is a very competent compliance officer responsible for monitoring these aspects who reports to the risk committee at each quarterly meeting'.

If one compares this to the responses received from CFOs, it is interesting to note that $94.1 \%$ of the CFOs felt that their audit committees are effective to a large extent as far as issues of business ethics go.

This huge discrepancy can only be attributed to poor disclosure by companies regarding their audit committee's responsibility pertaining to issues of business ethics.

In response to the question 'Which of the following business ethics responsibilities are performed by the audit committee you are the chair of?' the following information was provided by the various audit committee chairs:

TABLE 7: BUSINESS ETHICS-RELATED RESPONSIBILITIES

\begin{tabular}{lcc}
\hline Business ethics-related responsibilities & Number & $\%$ \\
\hline $\begin{array}{l}\text { Review compliance with the company's code of } \\
\text { ethics? }\end{array}$ & 22 & 64.7 \\
\hline $\begin{array}{l}\text { Review/Provide a channel for safe reporting } \\
\text { (whistle-blowing)? }\end{array}$ & 30 & 88.2 \\
\hline
\end{tabular}

Source: Audit committee chair questionnaire (authors' calculations)

Table 7 indicates that only 22 respondents (64.7\%) review compliance with their company's code of ethics. Given the growing importance of business ethics and the audit committee's role therein (as discussed previously), this is disappointing. It is more encouraging to see that 30 audit committees (88.2\%) are reviewing or providing a channel for whistle-blowing. Limited comments on this aspect were received, but the following are of interest:

- 'Review monthly reports from the provider of the whistle-blowing service.'

- 'The company has an ethics policy which is strictly enforced. The audit committee does not formally 
review compliance with the company's code of ethics, something I believe should be considered. The company has an ethics (whistle-blowing) line operated by independent suppliers. This is monitored independently by the group forensics department. The ethics line reports are at present only presented to the audit committee on an exception basis.'

- 'The above functions are performed by the sustainability committee.'

\section{Conclusion}

The renewed emphasis that is being placed on audit committees can be attributed to many factors, of which the major corporate collapses and business failures, fraudulent financial reporting, the issuing of various corporate governance codes, new or amended legislation and the harmonisation of accounting and auditing standards are the most important. The modern audit committee forms an integral part of the governance structures of the board and can be seen to act as the 'financial guard dog' of the shareholders specifically and of stakeholders at large. New and evolving responsibilities are entrusted to the modern audit committee, including oversight of the company's business ethics practices and conduct, as well as overseeing stakeholder reporting. The existence of an effectively functioning audit committee can bring many benefits to the company, including that of strengthening the control environment and business ethics practices and improving the quality and reliability of stakeholder reporting

From the empirical study it was also apparent that companies lack proper disclosure of their audit committee members' qualifications, experience and suitability for service on the audit committee. Few companies within the study provided information on whether their audit committee members are financially literate and even fewer stated whether they have the required financial expertise on their audit committees. Regarding the audit committee's role in strengthening business ethics and protecting stakeholders' interests, it was found that the majority of audit committee chairs believe their audit committees are effective in discharging their responsibilities regarding business ethics. Of concern are the findings that a large number of audit committees are not reviewing compliance with their companies' code of ethics, although most of them are reviewing or providing a channel for whistle-blowing, or safe reporting. The inspection of the annual reports further indicated a lack of disclosure by the companies' audit committees on their responsibilities performed in relation to business ethics.

\section{Note:}

${ }^{1} \mathrm{Mr}$ John Burke is the Executive Director of Listings at the JSE Limited, Sandton, South Africa.

\section{References}

Breckenridge, R.G. 2004. Modelling ethical corporate governance in terms of the King Report. Unpublished dissertation, University of the Witwatersrand, Johannesburg, South Africa.

Brewer, F.C. 2001. Corporate audit committee effectiveness. Unpublished dissertation, University of the Witwatersrand, Johannesburg, South Africa.

Bromilow, C.L. \& Berlin, L. 2005. Audit committee effectiveness - what works best (3rd edition). Altemonte Springs: The IIA Research Foundation.

Deloitte. 2006. The Duties of Directors. Deloitte, Johannesburg, South Africa.

Els, G. 2007. Utilising continued professional development of ethics amongst prospective chartered accountants. Unpublished doctoral thesis, University of Johannesburg, Johannesburg, South Africa.

Ernst \& Young. 2005. Audit committee benchmarking survey. Ernst \& Young, Johannesburg, South Africa.

Ernst \& Young. 2006. Fraud: Six myths that hold companies back. EYGM Limited. Score Retrieval File No. CX0015.

Ernst \& Young. 2007. Audit committee roles in fighting fraud: A network compendium. [Online]. Available: http://www. tapestrynetworks.com/documents/Tapestry_EY_Euro_ ACLN_Feb07_Insights2.pdf. Accessed on 4 November 2008.

Freeman, R.E. 1984. Strategic management: A stakeholder approach. Boston: Pitman.

Gatamah, K. 2006. The corporate enterprise in Africa: Governance, citizenship and social responsibility. Corporate Ownership \& Control, 1(3): 139-144.

Griseri, P. 1997. In search of business ethics. London: Financial Times Pitman Publishing.

Hadden, L.B. 2002. An investigation of the audit committee and its role in monitoring information technology risks. Unpublished doctoral dissertation, Nova Southeastern University, Fort Lauderdale-Davie, FL.

Heath, J. \& Norman, W. 2004. Stakeholder theory, corporate governance and public management: What can the history of state-run enterprises teach us in the postEnron era? Journal of Business Ethics, 53(3): 247-265.

Henning, E., Gravett, S.E. \& Van Rensburg, W. 2005. Find your way in academic writing (2nd edition). Pretoria: Van Schaik Publishers.

Holsti, O.R. 1969. Content analysis for the Social Sciences and Humanities. Reading, MA: Addison-Wesley.

Hutton-Wilson, D. 2001. Corporate governance: Critical challenges for South Africa. Management Today, 17(7): 8-13.

Institute of Directors (IoD). 2002. King II Report on Corporate Governance. Institute of Directors in Southern Africa, Johannesburg, South Africa.

Institute of Directors (IoD). 2009. King III Report on Corporate Governance. Institute of Directors in Southern Africa, Johannesburg, South Africa.

International Federation of Accountants (IFAC). 2002. The accounting profession and the fight against crime. [Online]. Available: http://www.ifac.org/council/ anticorruptionpaper.tmpl. Accessed on 4 November 2008. 
International Federation of Accountants (IFAC). 2005. Code of ethics for professional accountants. International Federation of Accountants, New York, NY

Jackson, K.T. 2006. Breaking down the barriers: Bringing initiatives and reality into business ethics education. Journal of Management Education, 30(1): 65-89.

JSE Limited (JSE). 2007. Ground rules for the management of the FTSE/JSE Africa index series. [Online]. Available: http://ftse.jse.co.za/does/general_information/FTSE_JSE_ Ground_Rules.pdf. Accessed on 4 November 2008.

JSE Limited (JSE). 2008. Indices constituents. [Online]. Available: http://fin.jse.co.za/findata/ indicesconstituanse.asp?sector $\mathrm{s}=\mathrm{J} 300 \& \mathrm{y}=115-123-85-65-100-125-119-89-82-66$. Accessed on 27 February 2008.

Kidder, R.M. 2001. There's only ethics ... Based on a keynote speech presented to the Human Services Council of Northeast Florida in Jacksonville on 1 October 1992, Institute for Global Ethics, FL.

King, M.E. 2006. The corporate citizen. Johannesburg: Penguin Books.

Knechel, R.W., Salterio, S.E. \& Ballou, B. 2007. Auditing assurance and risk (3rd edition). Canada: Thomson South Western.

Knights, D. \& O'Leary, M. 2005. Reflecting on corporate scandals: The failure of ethical leadership. Business Ethics: A European Review, 14(4): 359-366.

Landman, W. 2006. Wat sake-etiek behels [What does business ethics entail]. Finweek. (February 9, 2006). p. 49.

Leeman, M. 2002. What corporate citizenship and shareholder activism can reasonably be expected from trustees. South Africa: Frater Asset Management.

Maree, K.W. \& Radloff, S. 2007. Factors affecting ethical judgement of South African chartered accountants. Meditari, 15(1): 1-18.

PricewaterhouseCoopers. 2005. Audit committee effectiveness - what works best (3rd edition). Report by PricewaterhouseCoopers (sponsored by the Institute of Internal Auditors (IIA) Research Foundation, Altemonte Springs, FL).

Punt, W. 2006. Vyf stappe tot 'n kultuur van etiek [Five steps to a culture of ethics]. Finweek. (February 9, 2006). p. 50.

Robertson, J.C. 1993. Auditing (7th edition). Boston: Irwin.

Robins, F. 2006. Corporate Governance after SarbanesOxley: An Australian perspective. Corporate Governance, 6(1): 34-48.

Rossouw, D. 2002. Business ethics in Africa. New York: Oxford University Press.
Rossouw, D. 2003. The governance of ethical risk. Financial Mail (supplement). (June 13, 2003).

Rossouw, D. \& Van Vuuren, L. 2004. Business ethics. New York: Oxford University Press.

Rossouw, D., Prozesky, M., Van Heerden, B \& Van Zyl, M. 2007. Ethics for accountants and auditors. New York: Oxford University Press.

Schäckermann, U. 2007. Making sense of business ethics. Grant Thornton, South Africa.

Schwartz, M.S., Dunfee, T.W. \& Kline, M.J. 2005. Tone at the top: An ethics code for directors. Journal of Business Ethics, 58(1): 79-100.

Thomas, A. 2005. Corporate governance: A key challenge for South African leaders. Aboveboard: Africa's Global Chronicle on Governance, Leadership and Ethics, AugustSeptember, 1: 76-81.

Thomas, E. 2008. Business ethics - do we need them? BusinessBrief. (April/May 2008). p. 30.

Van Vuuren, L. 2003. Identifying and managing human resource risk. Financial Mail. (supplement). (June 27, 2003).

Voogt, T.L. 2008. Phase 1 of The SAICA CFO of the Future Project: A process report. Proceedings of the value 2008: Creating, developing and delivering value in Africa in the global context (Sun City, South Africa).

Weiss, R. 2005. Audit committee characteristics and monitoring effectiveness. Unpublished doctoral dissertation, University of New York, New York, NY.

Williams, P. 2006. An ethical dilemma. Accounting and Business. (February 2006). p. 14.

Williams, P. 2007a. Why can't audit committees behave as they should? Accounting and Business. (June 2007). p. 14.

Williams, P. 2007b. Teaching ethics. Accounting and Business. (July/August 2007). p. 12.

\section{Address correspondence to:} Gideon Els

Department of Finance and Investment Management University of Johannesburg

PO Box 524 Auckland Park, 2006

Johannesburg, South Africa e-mail: gels@uj.ac.za 


\section{Annexure}

TABle A: Companies INCLUded IN SAMPLE

ABSA Group Limited

African Rainbow Minerals Limited (ARM)

Anglo American PLC

Anglo Platinum PLC (Amplats)

Anglo Gold Ashanti Limited

Arcelor Mittal Steel South Africa Limited (Acelormittal)

Aveng Limited

Barloworld Limited

BHP Billing Limited

Bidvest Group Limited

Exxaro Resources Limited

First Rand Limited

Goldfields Limited

Harmony Gold Mining Company Limited (Harmony)

Impala Platinum Holdings Limited (Implats)

Imperial Holdings Limited

Investec Limited

Kumba Iron Ore Limited (Kumba)

Liberty Group Limited

Liberty International PLC
Lonmin Limited

Mondi Limited

MTN Group Limited

Murray \& Roberts Holdings Limited

Nasionale Pers Limited (Naspers)

Nedbank Group Limited

Network Healthcare Holdings Limited (Netcare)

Old Mutual PLC

Pretoria Portland Cement Limited (PPC)

Remgro Limited

Richemont Securities AG (Richemont)

RMB Holdings Limited

Sanlam Limited

Sappi Limited

Sasol Limited

SAB Miller PLC

Standard Bank Group Limited

Steinhoff International Holdings Limited (Steinhoff)

Telkom Limited

Tiger Brands Limited 
Reproduced with permission of the copyright owner. Further reproduction prohibited without permission. 